ISSN 0258-7122

Bangladesh J. Agril. Res. 40(2): 205-215, June 2015

\title{
RESPONSE OF ELEVATED TEMPERATURE ON CARBOHYDRATE ACCUMULATION AND GRAIN YIELD IN DIFFERENT WHEAT CULTIVARS
}

\author{
SOYEMA KHATUN ${ }^{1}$, AND JALAL UDDIN AHMED ${ }^{2}$
}

\begin{abstract}
In order to study the response of terminal heat stress on carbohydrate accumulation and grain yield of three wheat cultivars namely BARI Gom 25, BARI Gom 26 and Pavon 76 were sown on 18 November, 2011 in experimental field of Bangabandhu Sheikh Mujibur Rahman Agricultural University, Gazipur in Bangladesh and two temperature regimes viz. normal $\left(23^{\circ} \mathrm{C}\right.$ in open field $)$ and elevated $\left(6 \pm 1^{\circ} \mathrm{C}\right.$ higher compare to open field mean air temperature in polythene chamber) were created. Elevated temperature shortened the grain filling duration by 5-day in BARI Gom 25 and BARI Gom 26 and 10-day in Pavon 76. Under elevated temperature condition grain starch synthesis was found to be stopped at 25 days after anthesis (DAA) in Pavon 76 which in BARI Gom 26 appeared 5-day later (30 DAA) in spite of higher level of soluble sugar in grain. Results indicate that early failure of conversion of sugar to starch rather than supply of soluble sugar under elevated temperature condition were responsible for shortening of grain filling duration and smaller grain size in all wheat cultivars. Smaller reduction of grain size and grain number along with smaller reduction of grain weight per main stem under elevated temperature condition finally contributed to sustain negligible loss of grain yield, biological yield and harvest index in BARI Gom 25 and BARI Gom 26 compare to Pavon 76.
\end{abstract}

Keywords: Starch, soluble sugar, heat stress, wheat.

\section{Introduction}

In many wheat growing regions high temperature during post anthesis period are major factor limiting its productivity. Wheat is thermo sensitive crop. The optimum temperature for wheat growth ranged from $15^{\circ} \mathrm{C}$ to $18^{\circ} \mathrm{C}$ (Choudhury and Wardlaw 1978) but the temperature requirement of the crop during reproductive growth phases lies within $22^{\circ} \mathrm{C}$ for optimizing its grain yield (Campbell and Read 1968). In case of late sowing, temperature becomes stressful above $26^{\circ} \mathrm{C}$, when a premature ripening of wheat is taken place (Aborl et al. 1991) and producing poorly develop grain in wheat (Hasan and Ahmed 2005). Because the crop can not complete the major portion of grain filling period

${ }^{1}$ Scientific Officer, Bangladesh Institute of Nuclear Agriculture, BINA Sub-Station Ishurdi, RARS Campus Ishurdi, Pabna, ${ }^{2}$ Department of Crop Botany, Bangabandhu Sheikh Mujibur Rahman Agricultural University, Salna, Gazipur-1706, Bangladesh. 
before the temperature rises up to the critical level. High temperature during the reproductive stage and grain-filling is one of the main causes of yield loss in wheat in Bangladesh. Post-anthesis heat stress in wheat induces several physiological effect which eventually result in smaller grain weight due to reduced grain filling period and starch synthesis duration or the combined effect of both (Hasan and Ahmed 2005). Reduction of grain filling and starch synthesis duration is considered as one of the major environmental constraints that drastically reduce grain number per spike, grain size and grain weight per main stem and consequently significant reduction in wheat grain yield (Modhej et al. 2008, Gibson and Paulsen 1999).

Under Bangladesh condition a large number of findings are available regarding late planting induced heat stress effect on grain yield and yield attributes (Sikder and Paul 2010). In all of them, the temperature regimes were created by seeds sown on different sowing dates. There are fewer reports so far in which two temperature regimes were created by seeds sown on same day to study the response to terminal heat stress. This study was to investigate the response of elevated temperature on carbohydrate accumulation and grain yield in recently released wheat cultivars.

\section{Materials and Method}

The experiment was conducted at the research farm of Bangabandhu Sheikh Mujibur Rahman Agricultural University, Gazipur during November, 2011 to April, 2012. In this experiment recently released two potential heat tolerant wheat cultivars namely BARI Gom 25, BARI Gom 26 along with a heat sensitive check wheat cultivar Pavon 76 were planted using split plot design with four replications under two growing condition viz. open field temperature and elevated temperature (Polythene Chamber). Seeds were sown on 18 November, 2011 in rows of $20 \mathrm{~cm}$ apart (at the rate of $120 \mathrm{~kg} \mathrm{ha}^{-1}$ ). The unit plot size was $3 \mathrm{~m} \times 3 \mathrm{~m}$ having a plot to plot distance of $1.0 \mathrm{~m}$. In each of this $3 \mathrm{~m} \times 3 \mathrm{~m}$ plot, $1.5 \mathrm{~m} \times 1.0 \mathrm{~m}$ area was covered by transparent polythene sheet. The chambers were constructed using bamboo frame of $1.5 \mathrm{~m}$ high keeping $30 \mathrm{~cm}$ open space near the ground surface. Light intensity during maximum grain filling was found $1280 \mu \mathrm{mol} \mathrm{m}^{-2} \mathrm{~S}^{-1}$ in open field and $950 \mu \mathrm{mol} \mathrm{m}^{-2} \mathrm{~S}^{-1}$ in polythene chamber which is higher than its normal light intensity. Normal light intensity requirement for wheat was $610 \mu \mathrm{mol} \mathrm{m}^{-2} \mathrm{~S}^{-1}$ reported by Gerbaud and Marcel 1980. Cow dung $8500 \mathrm{~kg} \mathrm{ha}^{-1}$ and other fertilizers such as $\mathrm{N} 60 \mathrm{~kg} \mathrm{ha}^{-1}$ (as Urea), P $140 \mathrm{~kg} \mathrm{ha}^{-1}$ (as TSP), K $100 \mathrm{~kg} \mathrm{ha}^{-1}$ (as MOP) and S $110 \mathrm{~kg} \mathrm{ha}^{-1}$ (as Gypsum) were applied as per recommendation (FRG 2005). Irrigation was given to maintain more or less a 
field capacity and to avoid the drought stress. Mean air temperature was recorded everyday at noon period ( $2 \mathrm{pm}$ to $3 \mathrm{pm}$ ) using maximum-minimum thermometer from 5 days after anthesis (DAA) up to the maturity of each cultivar. Main shoot of 100 individual plants were tagged to confirm the equal exposure of elevated temperature starting the first appearance of anther emerged from the spike in each plant. Tagged ten spikes of main shoots were sampled at 5-day intervals starting from anthesis to 40 DAA and sampled spikes were oven dried at $70^{\circ} \mathrm{C}$ for 72 hours. After oven drying grains were sampled from the middle portion of the spike and their weight was taken with analytical balance (Model: AGN220C). The grain samples were used for sugar and starch analysis. Soluble sugar and starch content of grain was determined using the method of Yoshida et al. (1976).

Plants were hand-harvested by cutting them at ground level. Then grain 1000grain weight, grain number per spike and grain dry weight per main stem was measured. The husk, straw and representative samples of grain were dried in sun properly to obtain grain yield and biological yield expressed in $t / h a$. Harvest index was calculated by the following formula-

Harvest index $(\%)=\frac{\text { Economical yield }}{\text { Biological yield }} \times 100$

The relative performance was calculated as Asana and Williams (1965) by the following formula-

Relative Performance $(\%)=\frac{\text { Variable measured under stress condition }}{\text { Variable measured under normal condition }} \times 100$

All statistical analyses were performed by MSTAT-C program. The treatment means were compared using Duncan's Multiple Range Test (DMRT) at 5\% level of significance. Graphical representation and simple data were calculated by using Microsoft Excel.

\section{Results and Discussion}

Wheat cultivars were grown in open field temperature condition where daily mean temperature during reproductive growth stage was recorded $23^{\circ} \mathrm{C}$ (ranging from 18.5 to $25.5^{\circ} \mathrm{C}$ ) (Fig. 1). But under elevated temperature condition in polythene chamber the daily mean temperature was raised by $6 \pm 1^{\circ} \mathrm{C}$ compare to open field mean air temperature. Generally optimum temperature for reproductive stages of wheat lies within a range of $22-26^{\circ} \mathrm{C}$ temperature (Campbell and Read 1968; Mullarkey and Jones 2000; Tewolde et al. 2006) and premature ripening of grain was occurred above $26^{\circ} \mathrm{C}$ (Aborl et al. 1991). 


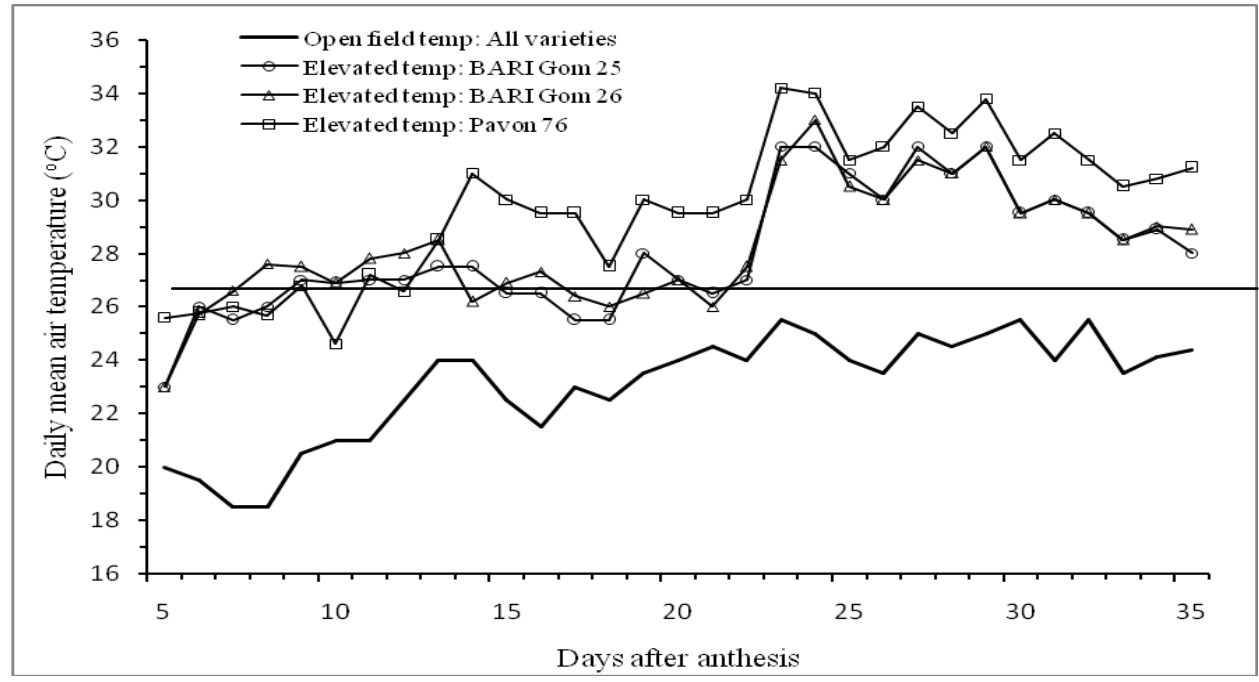

Fig. 1. Daily mean air temperature received by three wheat cultivars from 5 to 35 DAA under open field and elevated temperature conditions. Horizontal line indicates the critical level of temperature for grain growth of wheat.

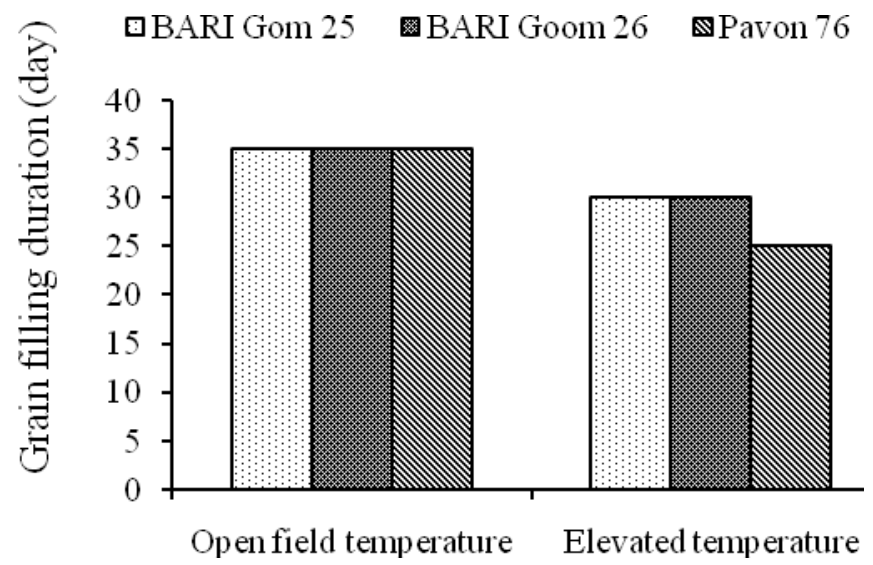

Fig. 2. Grain filling duration in three wheat cultivars under open field and elevated temperature condition.

Elevated temperature condition accelerated the physiological maturity of all wheat cultivars and hence reduced their grain filling duration. Under elevated temperature condition grain filling duration was 25-day in Pavon 76 and 30-day in BARI Gom 25 and BARI Gom 26 (Fig. 2). But under open field temperature condition grain filling duration in all wheat cultivars were 35-day. Therefore due to elevated temperature grain filling duration was reduced by 5-day in two BARI Gom cultivars and by 10-day in Pavon76. Reports are available on heat stress 
about shortened grain filling period (Dias and Lidon 2009). Varietal difference in reduction of grain filling duration was also reported in wheat indicating a larger reduction in heat sensitive cultivars compared to heat tolerant cultivars (Hasan and Ahmed 2005).

Because of similar variation of grain filling duration out of two wheat cultivars BARI Gom 25 and BARI Gom 26, finally BARI Gom 26 was taken to compare with Pavon 76 for grain starch and soluble sugar analysis. Result indicate that percent of maximum starch content reached the highest level at 35 DAA in both of the wheat cultivars (BARI Gom 26 and Pavon 76) under open field temperature condition (Fig. 3.A). But under elevated temperature condition that reached the highest level at 30 DAA in BARI Gom 26 and at 25 DAA in pavon 76 (Fig. 3.A). Thus compared to BARI Gom 26, starch synthesis was stopped about 5-day earlier in Pavon 76 due to elevated temperature conditions. It was clearly indicate that heat stress effect was more pronounced in Pavon 76 and also appeared here that the end of grain filling duration and starch synthesis duration was almost equal in both of the wheat cultivars and growing temperature condition.

A higher level of grain soluble sugar was found up to 20 DAA in BARI Gom 26 under open field temperature condition compared to elevated temperature condition, which was found in Pavon 76 for 15-day (Fig. 4.B). Afterwards soluble sugar content was lower under open field temperature condition compare to elevated temperature condition in both cultivars.

A

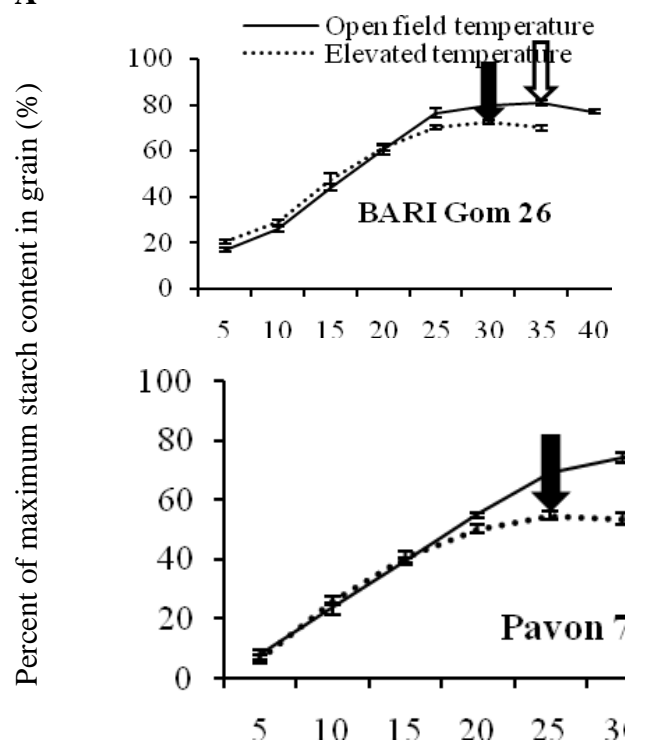

Days after sowing

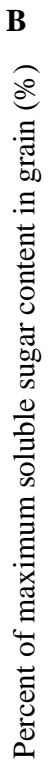

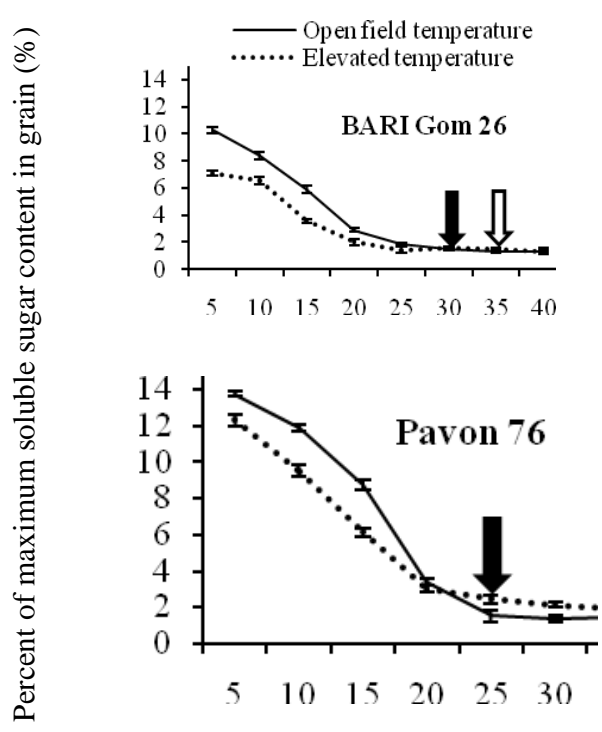

Days after sowing

Fig. 3. (A) Percent of maximum starch and (B) soluble sugar content in grain of two wheat cultivars from 5 DAA to maturity under open field and 
elevated temperature condition. Unfilled and filled arrows indicate physiological maturity of wheat cultivars under open field and elevated temperature conditions, respectively. Vertical lines are standard errors of selected data point.
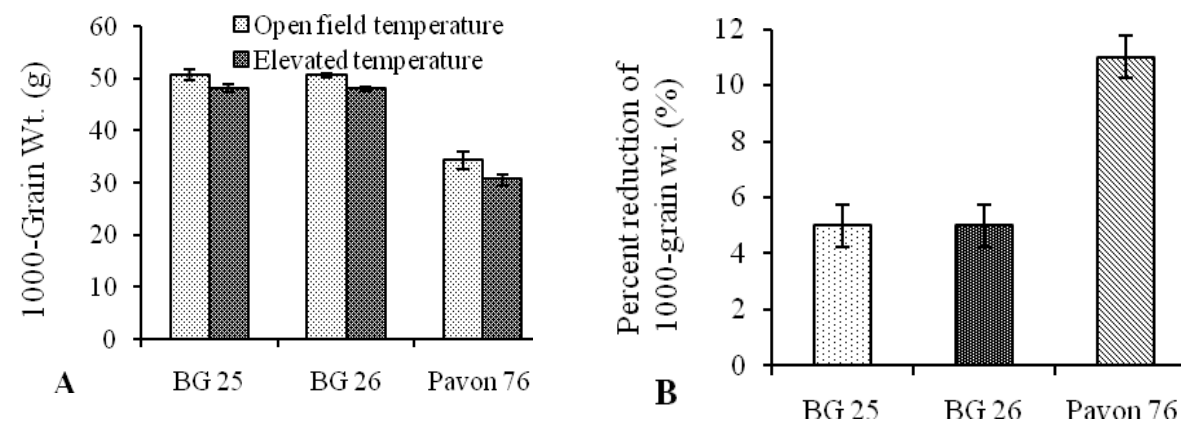

Wheat cultivars

Fig. 4. (A) Weight of 1000-grain and (B) percent reduction of 1000-grain weight of three wheat cultivars under open field and elevated temperature condition. Vertical lines are standard errors of mean data point.

At physiological maturity, it is clearly noticed that the grain starch synthesis was terminated in presence of adequate amount of grain soluble sugar under elevated temperature condition due to some limiting factors in synthesis of starch from soluble sugar in grain. Premature of grain development under heat stress condition had been reported due to limited enzymatic function involving sugar to starch conversion (Denyer et al. 1994; Jenner 1994; MacLeod and Duffus 1988). It appeared here that elevated temperature restricted starch synthesis more prominent in heat sensitive cultivars compare to heat tolerant cultivars (Yang et al. 2002; Hasan and Ahmed 2005).

Under elevated temperature condition 1000-grain weight was reduced in all wheat cultivars. Such reduction was more pronounced through percent reduction of 1000-grain weight. Maximum reduction of 1000-grain weight was observed in Pavon 76 and minimum in BARI Gom cultivars due to high temperature (Fig. 4). Under elevated temperature condition poor grain development in Pavon 76 compared to the other genotypes was contributed by the heat sensitiveness of grain filling and starch synthesis duration. High temperature enhanced the reduction in grain filling duration which ultimately resulted in smaller grains (Rahman et al. 2005). 
Under open field temperature condition, Pavon 76 had the maximum number of grain per spike (56.38/spike) but under elevated temperature condition the highest grain number was observed in BARI Gom 26 (47.65/spike) (Fig. 5.A). Pavon 76 showed the maximum reduction $(25 \%)$ in number of grain per spike (Fig. 5.B) due to completely failure of grain development for poor cell division and cell enlargement in grain under high temperature condition. Result indicated that Pavon 76 affected more than BARI Gom 25 and BARI Gom 26 in producing grain number per spike at high temperature inside the polythene chamber. Exposure to high temperature above $30^{\circ} \mathrm{C}$ during 10 to 14 days after anthesis have been reported to contribute to the reduction of grain number in wheat by affecting primarily cell division and subsequently cell enlargement (Gibson and Paulsen 1999). Significant reduction in grain number in different wheat cultivars under elevated temperature was also found by Viswanathan and Khanna-Chopra 2001; Sail et al. 2005; Tahir and Nakata 2005 and Wollenweber et al. 2003.

The maximum percent reduction of grain dry weight per main stem ear was observed in Pavon 76 (22\%) where as $11 \%$ in BARI Gom 25 and $8 \%$ in BARI Gom 26 (Fig. 6.B). The result prevailed that Pavon 76 affected more than other BARI Gom cultivars in producing grain dry weight per main stem ear under elevated temperature condition which was contributed to the maximum reduction of 1000-grain weight and grain number per spike in Pavon 76. Increasing temperature (from 30 to $38^{\circ} \mathrm{C}$ ), during reproductive phase, reduced the main stem grain weight by 20 to $44 \%$ (Tahir and Nakata 2005). A significant reduction in main stem grain weight difference in five wheat cultivars had been reported by Fokar et al. 1998b. However in present experiment, the reduction of main stem grain weight was 8 to $22 \%$ by raising daily mean temperature from $23^{\circ} \mathrm{C}$ to $29^{\circ} \mathrm{C}$ during post anthesis period.

Under elevated temperature maximum grain yield observed in BARI Gom 26 which was followed by BARI Gom 25 and the lowest grain yield observed in Pavon 76 which was statistically different from other cultivars (Table 1). The maximum percent reduction in grain yield and biological yield were observed in Pavon 76 than those in BARI Gom cultivars (Fig.7). 

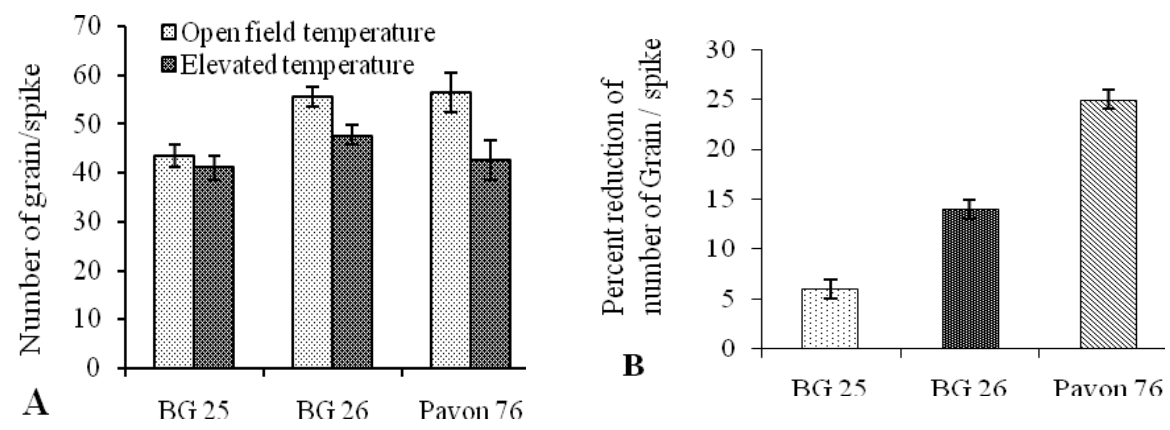

Wheat cultivars

Fig. 5. (A) Number of grain per spike and (B) percent reduction of number of grain perspike of three wheat cultivars under open field and elevated temperature condition. Vertical lines are standard errors of mean data point.
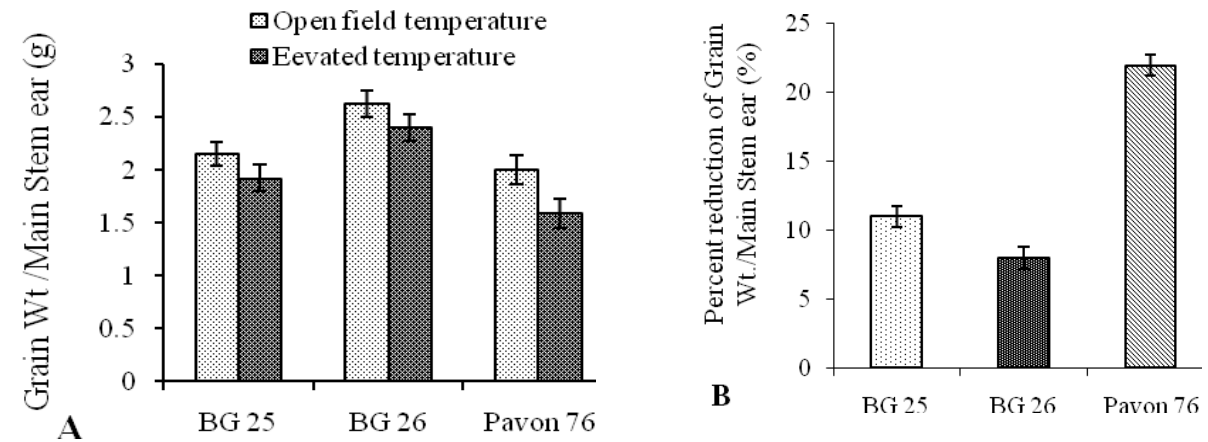

Wheat cultivars

Fig. 6. (A) Grain dry weight per main stem ear and (B) percent reduction of grain dry weight per main stem ear of three wheat cultivars under open field and elevated temperature condition. Vertical lines are standard errors of mean data point.

Table 1. Grain yield, Biological yield and harvest index in three wheat cultivars under open field and elevated temperature condition

\begin{tabular}{lcccccc}
\hline \multirow{2}{*}{ Cultivars } & \multicolumn{2}{c}{ Grain yield (t/ha) } & \multicolumn{2}{c}{ Biological yield (t/ha) } & \multicolumn{2}{c}{ Harvest index (\%) } \\
\cline { 2 - 7 } & $\begin{array}{c}\text { Open field } \\
\text { temp. }\end{array}$ & $\begin{array}{c}\text { Elevated } \\
\text { temp. }\end{array}$ & $\begin{array}{c}\text { Open field } \\
\text { temp. }\end{array}$ & $\begin{array}{c}\text { Elevated } \\
\text { temp. }\end{array}$ & $\begin{array}{c}\text { Open field } \\
\text { temp. }\end{array}$ & $\begin{array}{c}\text { Elevated } \\
\text { temp. }\end{array}$ \\
\hline BARI Gom 25 & $4.59^{\mathrm{a}}$ & $4.15^{\mathrm{c}}$ & $10.30^{\mathrm{a}}$ & $9.42^{\mathrm{c}}$ & $48.15^{\mathrm{a}}$ & $44.09^{\mathrm{b}}$ \\
BARI Gom 26 & $5.07^{\mathrm{a}}$ & $4.38^{\mathrm{b}}$ & $10.85^{\mathrm{a}}$ & $9.89^{\mathrm{bc}}$ & $46.77^{\mathrm{ab}}$ & $44.32^{\mathrm{b}}$ \\
Pavon 76 & $4.38^{\mathrm{b}}$ & $3.39^{\mathrm{d}}$ & $9.92^{\mathrm{bc}}$ & $8.53^{\mathrm{d}}$ & $44.10^{\mathrm{b}}$ & $39.72^{\mathrm{c}}$ \\
\hline
\end{tabular}

Values in a column with different letter are significantly different at $P \leq 0.05$ by DMRT. 

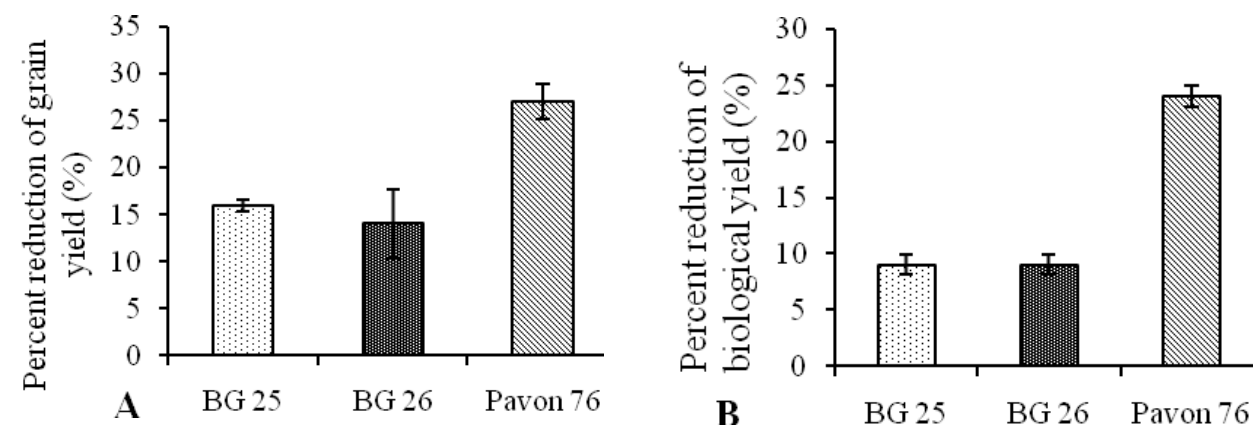

Wheat cultivars

Fig. 7. (A) Percent reduction of grain yield and (B) biological yield of three wheat cultivars under open field and elevated temperature condition. Vertical lines are standard errors of mean data point.

Pavon 76 was affected more in grain yield and biological yield than BARI Gom 25 and BARI Gom 26 under elevated temperature condition due to maximum reduction in grain weight per main stem ear. Exposure to temperatures above $26^{\circ} \mathrm{C}$ this can significantly reduce grain yield (Mullarkey and Jones 2000; Sail et al. 2005; Tewolde et al. 2006). Significant variation in different wheat cultivars was also found by Hasan and Ahmed 2005.

Under elevated temperature the lowest harvest index was observed in Pavon 76 which was statistically lower than the other two wheat cultivars (Table 1). Harvest index decreased with an increase in mean temperature above $20^{\circ} \mathrm{C}$ applied 10 days after anthesis until ripeness (Gibson and Paulsen 1999).

Elevated temperature reduced grain filling and starch synthesis duration which contributed to the reduction of grain size and grain weight per main stem that finally contributed to the reduction of grain yield. The elevated temperature during post anthesis period had more effect in Pavon 76 in terms of grain filling and starch synthesis duration which contributed to sustained prominent loss of grain yield, biological yield and harvest index in Pavon 76. On the other hand the minimal effect of elevated temperature finally contributed to sustain negligible loss of grain yield, biological yield and harvest index in BARI Gom 25 and BARI Gom 26.

\section{Acknowledgement}

This work was conducted as part of MS thesis of first author for Bangabandhu Sheikh Mujibur Rahman Agricultural University, Salna, Gazipur-1706. Authors are grateful to the university authority for help rendering during this study. 


\section{References}

Aborl Y P, Bagga A K, Chakravarty N V K and Wattal P N (1991), Impact of rise in temperature on the productivity of wheat in India. In:Abrol YP et al., Impact of global climatic change on photosynthesis and plant productivity, Oxford and IBH Pub. New Delhi, India.

Asana R D and Williams R F (1965), The effect of temperature stress on grain development in wheat, Aust. J. Agric. Res, Pp.16: 1-3.

Campbell C A and Read D W L (1968), Influence of air temperature, light intensity and soil moisture on the growth, yield and some growth analysis characteristics of chioiolo wheat grown in the growth chamber, Can. J. Plant Sci. 48: 299-311.

Chowdhury S I and Wardlaw I F (1978), The effect of temperature on kernel development in Cereals, Aust. J. Agric. Res. 29: 205-223.

Denyer K, Hylton C M and Smith A M (1994), The effect of high temperature on starch synthesis and the activity of starch synthase, Aust. J. Plant Physiol. 21: 783-789.

Dias A S and Lidon F C (2009), Evaluation of grain filling rate and duration in bread and durum wheat, under heat stress after anthesis, J. Agron. Crop Sci. 195: 137-147.

Fokar, Blum M A and Nguyen H T (1998b), Heat tolerance in spring wheat. II. Grain filling. Euphytica, Pp. 104: 9-15.

FRG (2005). Fertilizer Recommendation Guide. Bangladesh Agricultural Research Council (BARC). Farmgate, Dhaka.

Gerbaud Alain and Marcel Ander (1980), Effect of $\mathrm{CO}_{2}, \mathrm{O}_{2}$, and Light on Photosynthesis And Photo respiration in Wheat, Plant Physiol. 66: 1032-1036.

Gibson L R and Paulsen G M (1999), Yield components of wheat grown under high temperature stress during reproductive growth, Crop Sci. 39:1841-1846.

Hasan M A and Ahmed J U (2005), Kernel growth physiology of wheat under late planting heat stress, J. Natn. Sci. Foundation Sri Lanka. 33(3):193-204.

Jenner C F (1994), Starch synthesis in the kernel of wheat under high temperature conditions, Funct. Plant Biol. 21: 791-806.

Macleod L C and Duffus C M. (1988), Reduced starch content and sucrose synthase activity in developing endosperm of barley plants grown at elevated temperatures, Aust. J. Plant Physiol. 15: 367-375.

Modhej A, Naderi A, Emam Y, Aynehband A and Normohamadi G (2008), Effects of post-anthesis heat stress and nitrogen levels on grain yield in wheat (T. durum and $T$. aestivum) cultivars, Inter J Plant Pro. 2: 254-267.

Mullarkey M and Jones P (2000), Isolation and analysis of thermo tolerant mutants of wheat, J. Exp. Bot. 51: 139-146.

Rahman M A, Chikushi J, Yoshida S, Yahata H and Yasunsga B (2005), Effect of high air temperature on grain growth and yields of wheat genotypes differing in heat tolerance, J. Agric. Meteorol. 60: 605-608. 
Sail M A, Arain M A, Shamadad K, Naqvi M H, Dahot M U and Nizamani N A (2005), Yield and quality parameters of wheat genotypes as affected by sowing dates and high temperature stress, Pakistan J. Botany. 37(3): 575-584.

Sikder S, Paul N K (2010), Effect of Post Anthesis Heat Stress on Stem Reserves Mobilization, Canopy temperature Depression and Floret Sterility of Wheat cultivar, Bangladesh J. Bot. 39(1): 51--55.

Tahir I S A and Nakata N (2005), Remobilization of nitrogen and carbohydrate from stems of bread wheat in response to heat stress during grain filling, J. Agron. Crop Sci. 191: 106-115.

Tewolde H, Fernandez C J and Erickson C A (2006), Wheat cultivars adapted to postheading high temperature stress, J. Agron. Crop Sci. 192: 111-120.

Viswanathan C and Khanna-Chopra R (2001), Effect of heat stress on grain growth, starch synthesis and protein synthesis in grains of wheat (Triticum aestivum L.) varieties differing in grain weight stability, J. Agron. Crop Sci. 186: 1-7.

Wollenweber B, Porter J R and Schellberg J (2003), Lack of interaction between extreme

high temperature events at vegetative and reproductive growth stages in wheat, J. Agron and Crop Sci. 189: 142-150.

Yang J, Sears R G, Gill B S and Paulsen G M (2002), Genotypic differences in utilization of assimilate sources during maturation of wheat under chronic heat and heat shock stresses, Euphytica 125: 179-188.

Yoshida S, Forno D A, Cock J H and Gomez K A (1976), Laboratory Manual for Physiological Studies of rice (Third edition), The International Rice Research Institute, Los Banos, Laguna, Philippines, Pp. 46-49. 